\title{
原著
}

\section{口蓋部床用材料が上顎全部床義歯の 機械的特性に及ぼす影響}

\author{
高山義 明 \\ 東京医科米科大学歯学部第 3 歯科補経学教室（指導：長尾正憲教授）
}

(1988年 6 月30日 受付)

\section{Influence of Denture Base Material Used for Palate on Mechanical Properties of Upper Complete Denture}

\section{Yoshiaki Takayama}

The 3rd Department of Prosthodontics, Faculty of Dentistry, Tokyo Medical and Dental University (Director : Prof. Masanori Nagao)

Denture bases are mainly classified into resin denture base and metal denture base according to the denture base material used. In this paper the influence of these material on the mechanical properties of the upper complete dentures was studied. The test denture bases were acrylic resin denture base, carbon fiber (CF)-cloth reinforced acrylic resin denture base, stainless steel swaged metal base using 4-META adhesive resin and $\mathrm{Co}-\mathrm{Cr}$ alloy cast metal base. The mechanical properties of these denture bases were evaluated by the uniform-moment bending method, considering the loading in the occlusal situation.

The findings are as follows : $\mathrm{Co}-\mathrm{Cr}$ alloy cast metal and stainless steel swaged metal have high Young's modulous and strength in comparison with those of acrylic resin and CF-cloth reinforced acrylic resin. But, the denture base as a construction had not large difference of the mechanical properties between these four denture base material. Therefore, it would be suggested that the denture base material used for palate had not more influence on the mechanical properties of the upper complete denture.

\section{I．緒言}

義料林は使用される休用材料によりレジン床と 金属床とに大別されるが，従来アクリリックレジ ンをベースとする前者は, 後者に比べ操作性や経 済性などの長所を有することから沉用されてい る。しかし，レジン床は金属床より剛性や強度が 低いことから，レジン床の剛性括よび強度の向上 を計る試みとして，ポリサルホン，ポリエーテル
サルホン，繊維強化樹脂などの忘用が娭討されて きた $\left.{ }^{2} 3\right)$ 。最近，4-META 含有の金属接着性レ ジンが開発され，压印床を含さ金属床が再び注目

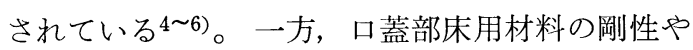
強度が義歯床の機械的特性に及ぼす影響について 比較検討を行った報告は少ない7)。

本報では口蓋部床用材料が義歯床に及ぼす力学 的効果を検討するため, 口蓋部床用材料としてア クリリックレジン, カーボン繊維クロス強化樹 
脂，ステンレス圧印床 およびCo-Cr 系合金鋳造 床について，咬合時に義歯床に加わる荷重状態を 想定した一様曲げモーメントを上顎全部床義歯に 加えることによりその変形を測定し, 応力の解析 を行った。実験は, 通常の口蓋形態を対象として 製作した全部床義歯試験片について 4 点曲げ試験 を実施し，そのときのたわみおよび床口蓋部に貼 付した電気抵抗線ひずみゲージによりひずみ分布 を同時に測定した。

\section{II. 材料と方法}

\section{1. 材 料}

本実験では, 応用材料として表 1 に示すと拉り， 市販の義歯床用アクリリックレジン (PMMA), カーボン繊維 クロス（トレカクロス S742）を強 化材とし床用アクリリックレジンをマトリックス とした繊維クロス強化樹脂 (CFRP)，ステンレス (SUS 304) 圧印床特よびCo-Cr 系合金鋳造床につ いておのおの 5 つずつ，合計20の試験片を作製し た。ただし，ステンレス圧印床試験片はレジンの 保持装置を付与せず8)，4-META 含有 (5wt\%) の床用レジン（加熱重合タイプ，色調：無色）を 使用し，他の試験片は 4-META を含有しない林 用レジン（加熱重合タイプ，色調：無色）を使用 した。各試験片は図 $1 ， 2$ に示すように，前歯部 のみ既製のレジン歯を排列し，臼歯部に鋼製ウィ ング（厚さ $2.5 \mathrm{~mm}$ ）を取り付けた左右対称な上
顎全部床義歯とし，歯科の通法に従い加熱重合し 作製した。図中，破線および床後縁で团む領域の 厚さをマイクロメータにて测定し床口蓋部の厚さ とした。な招，各義歯床は表 1 に示すように略 記号を与光，レジン床を RD，カーボン繊維クロ スを埋入した義歯床を FD，ステンレス压印床を $\mathrm{PD}, \mathrm{Co}-\mathrm{Cr}$ 系合金鋳造床を $\mathrm{CD}$ と示すことにす る。

\section{2. 方 法}

図 3 は, 負荷装置の寸法を示したもので，全部 床義歯試験片に一椂曲げモーメントが作用するよ 万 4 点曲げ試験方法を採用した。測定は，万能材 料試験機（島津製 IS-5000型）を使用してクロス ヘッド速度 $1 \mathrm{~mm} / \mathrm{min}$ で破壞点まで連続的に負 荷し，義歯床正中線上切歯乳頭部から床後縁まで 等間隔に貼付した 5 枚のプラスチック用ひずみゲ ージ（共和電業製 KFP-2-Cl-65）および万能ディ

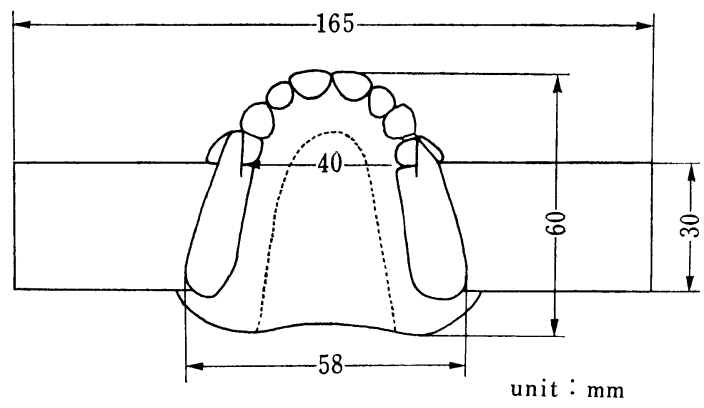

図 1 上顎全部床義歯試験片の形状および寸法

表 1 各種試験片口蓋部を構成する材料

\begin{tabular}{lcccc}
\hline \multicolumn{1}{c}{ Denture base } & $\begin{array}{l}\text { Symbol of } \\
\text { denture base }\end{array}$ & Palatal area & Another area & $\begin{array}{c}\text { Thickness of } \\
\text { palatal area } \\
(\mathrm{mm})\end{array}$ \\
\hline $\begin{array}{l}\text { Resin denture } \\
\text { base }\end{array}$ & RD & PMMA & PMMA & 1.6 \\
$\begin{array}{l}\text { Carbon fiber cloth } \\
\text { reinforced resin } \\
\text { denture base }\end{array}$ & FD & CFRP & PMMA & 0.9 \\
$\begin{array}{l}\text { Swaged metal } \\
\text { denture base }\end{array}$ & PD & SUS304 & PMMA & \\
$\begin{array}{l}\text { Cast denture } \\
\text { base }\end{array}$ & CD & Co-Cr alloys & PMMA & 0.4 \\
\hline
\end{tabular}




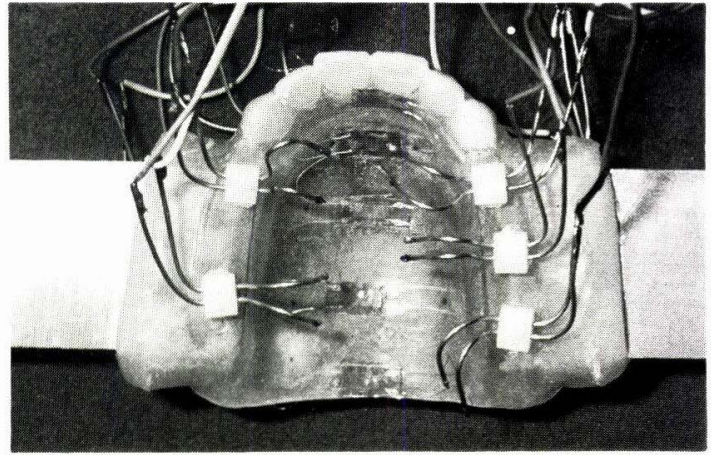

(a)

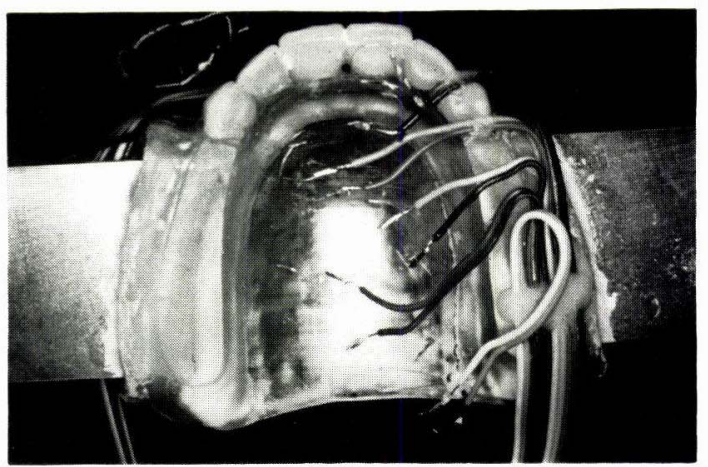

(c)

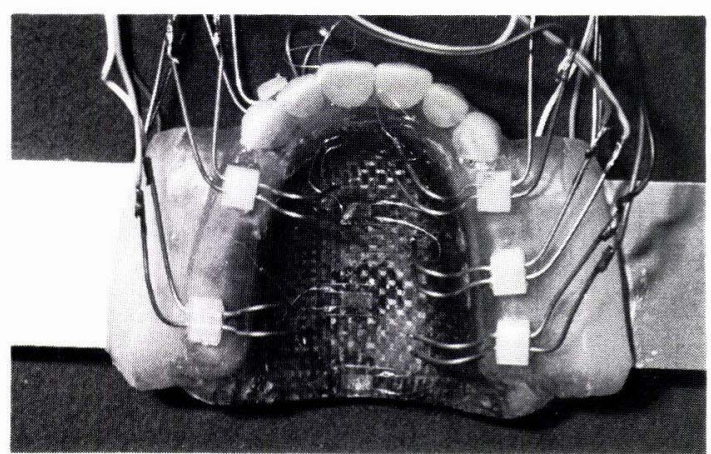

(b)

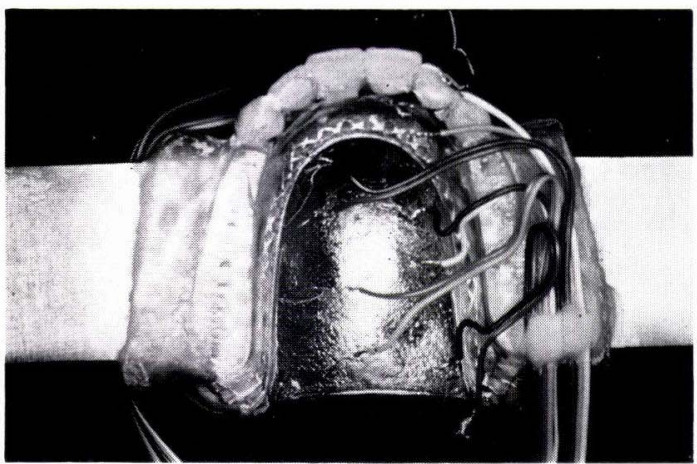

(d)

図2 各種試駼片のゲージ貼付状沉

(a)：レジン休(RD), (b)：纎維绌化樹脂休(FD),

(c)：ステンレス压印床 $(\mathrm{PD}),(\mathrm{d}): \mathrm{Co}-\mathrm{Cr}$ 系銧造林 (CD)

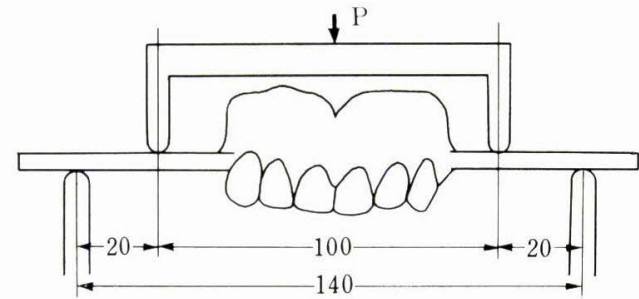

unit : mm

成 34 点曲げ試駖装置の概略と寸法

ジタル測定機（共和電業製 UCAM-8 BL）を用い てそのときのたわみ拉よびひずみを測定した。

\section{III. 結果および考察}

\section{1. 義歯床の曲げ剛性}

衣 2 は，本験に使用した口蓋部床用材料の機
悈的性質9,10)を示したものである。本尖験では, これらの床用材料が上顎全部床義歯の曲げ岡性に どの程度影響を及ぼすかについて検討を行った。 四 4 は RD，FD，PD 拉よ゙゙CD について 4 点曲 げ試験を笑施した結果を示すものである。縦軸に 曲げモーメント，横軸に荷車点部の変位㫣すなわ ちたわみ量を表している。

各義歯床とも曲げモーィント $\mathrm{M}=400 \mathrm{kgf} ・ \mathrm{~mm}$ までの负荷領域では，口盍部床用材料が異なるに もかかわらず両者の関係は注洫線的に推移し， 義雨休の曲げ岡性は CD が最も高く, ついで $\mathrm{PD}$, $\mathrm{FD}, \mathrm{RD} の$ 順であった。各口蓋部床用材料の縦弾 性係数を比較すると, PMMA の縦弾性係数に比 べCFRP では約 4 倍, SUS 304 では約73倍, CoCr 系介食では約90倍を示しているが，義雨床の 
表 2 各種試験片口蓋部を構成する材料の機械的性質

\begin{tabular}{lcccc}
\hline Material & $\begin{array}{c}\text { Elastic modulus } \\
\mathrm{E}\left(\mathrm{kgf} / \mathrm{mm}^{2}\right)\end{array}$ & $\begin{array}{c}\text { ratio } \\
\mathrm{E} / \mathrm{E}_{\mathrm{PMMA}}\end{array}$ & $\begin{array}{c}\text { Tensile strength } \\
\boldsymbol{\sigma}\left(\mathrm{kgf} / \mathrm{mm}^{2}\right)\end{array}$ & $\begin{array}{c}\text { ratio } \\
\sigma / \sigma_{\text {PMMA }}\end{array}$ \\
\hline PMMA & 290 & 1.0 & 6.9 & 1.0 \\
CFRP & 1,150 & 4.0 & 8.3 & 1.2 \\
SUS304 & 21,300 & 73.4 & $50 \sim 110$ & $7.3 \sim 15.9$ \\
Co-Cr alloys & 26,000 & 89.7 & 95.6 & 13.9
\end{tabular}

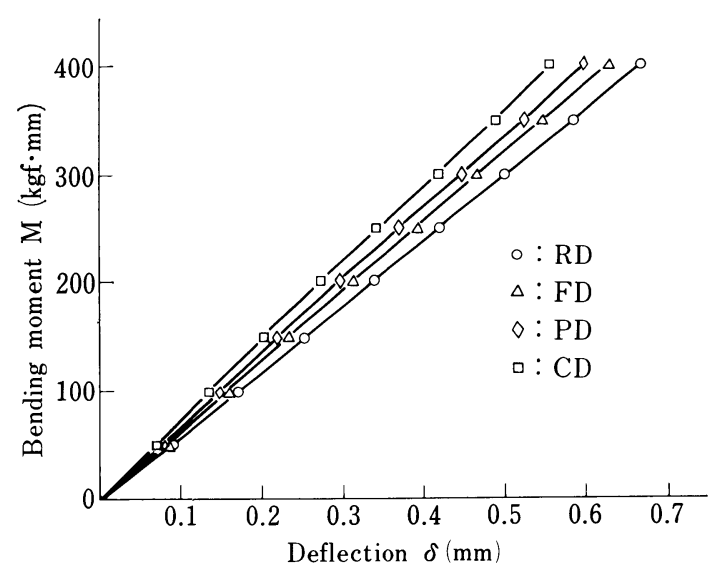

図 4 上顎全部床義茵試験片の曲げモーメント $(\mathrm{M})$-たわ和 $(\grave{o})$ 線図 $(\mathrm{M}=0$ to $400 \mathrm{kgf} \cdot \mathrm{mm})$

曲げ岡性はRDに比較して順に，約 $21 \% ， 11 \%$, $8 \%$ 増加となっている。また，床口蓋部の平 均の厭さは $\mathrm{PD}$ が最も薄く, $\mathrm{RD}$ と比較して約 25 \%, CD では約 $38 \%, \mathrm{FD}$ では約53\%であった。 したがって，上顎全部床義歯の口蓋部全体に PMMA より弾性係数の高い床用材料を用いた場 合でも，臨床上用いられている床の厚さでは義歯 床全体の曲げ岡性を大きく向上させることは期待 できない。

$\mathrm{FD}, \mathrm{PD}$ 扨よび CD 間では，FDは CFRP の縦 弾性係数が $\mathrm{Co}-\mathrm{Cr}$ 系合金の約 $4 \%, \quad$ SUS 304 の 約 $5 \%$ であるが，義歯床全体の曲げ剛性は CD の 約 $89 \%, \mathrm{PD}$ の約 $97 \%$ を示し, カーボン繊維クロ スによる補強効果が義歯床の曲げ岡性の向上に寄 与していることが示される。

\section{2. 義菌床のひずみ分布}

网 5 は，各義歯床に貼付した 5 点のゲージ位置 に生じたひずタを，曲げモーィント $\mathrm{M}=0$ から
$400 \mathrm{kgf} ・ \mathrm{~mm}$ まで $\mathrm{M}=50 \mathrm{kgf} ・ \mathrm{~mm}$ 間隔で測定し たものである。横軸は曲げモーメントを，縦軸 は義歯床正中線上に生じたひずみ量を表してい る。

義歯床のひずみ分布は口蓋部床用材料が異なる にもかかわらず，全体的に同様な傾向を示してい る。すなわち, (1)の切雨乳頭部では顕著な引張ひ ずみを示し，他の 4 部位では低い值を示した。ま た，唇側中切歯歯間乳頭部下では各義歯床とも同 様に低い圧縮ひずみを示した。次に，床口蓋部に 用いけ床用材料が義歯床のひずみ分布に及ぼす影 響について観察すると, 義歯床全体で顕著な引張 ひずみを示す(1)の切歯乳頭部付近では各義歯床と も而者の関係は直線的に推移し, RD が最大で, $\mathrm{FD}, \mathrm{PD}, \mathrm{CD}$ の順に小さい值を示した。これを $\mathrm{RD}$ と比較した場合, CFRPを口蓋部床用材料と して用いた FD では約13\%の減少, SUS 304 の テンレス压印床を用いた PD では約 $17 \%$ の減少, $\mathrm{Co}-\mathrm{Cr}$ 系合金の鋳造床を用いた CD では約 $23 \%$ の 減少を示し, 剛性の高い床用材料洼ど切歯乳頭部 ではひずみ量が減少する傾向を示した。(2)打よび (3)では研磨面側, 粘膜面側ともに低い圧縮ひずみ を生じ，(3)では剛性の高い床用材料を用いた義歯 床はひずみ量が減少した。(4), (5)の床後縁付近で は, 剛性の高いPD, CD に敃いて研磨面側では引 張ひずみ，粘膜面側では压縮ひずみを示し，義歯 床縁が粘膜面から離れる方向に曲げ挙動を示し た。一方, 剛性の比較的低いFD および RD では 研磨面側, 粘膜面側ともに压縮を示した。

上顎全部床義歯の床口蓋部全体に剛性の異なる 休用材料を用いた場合, 顕著な差は認められない ものの剛性の高い材料ほど義歯床のひずみは全体 


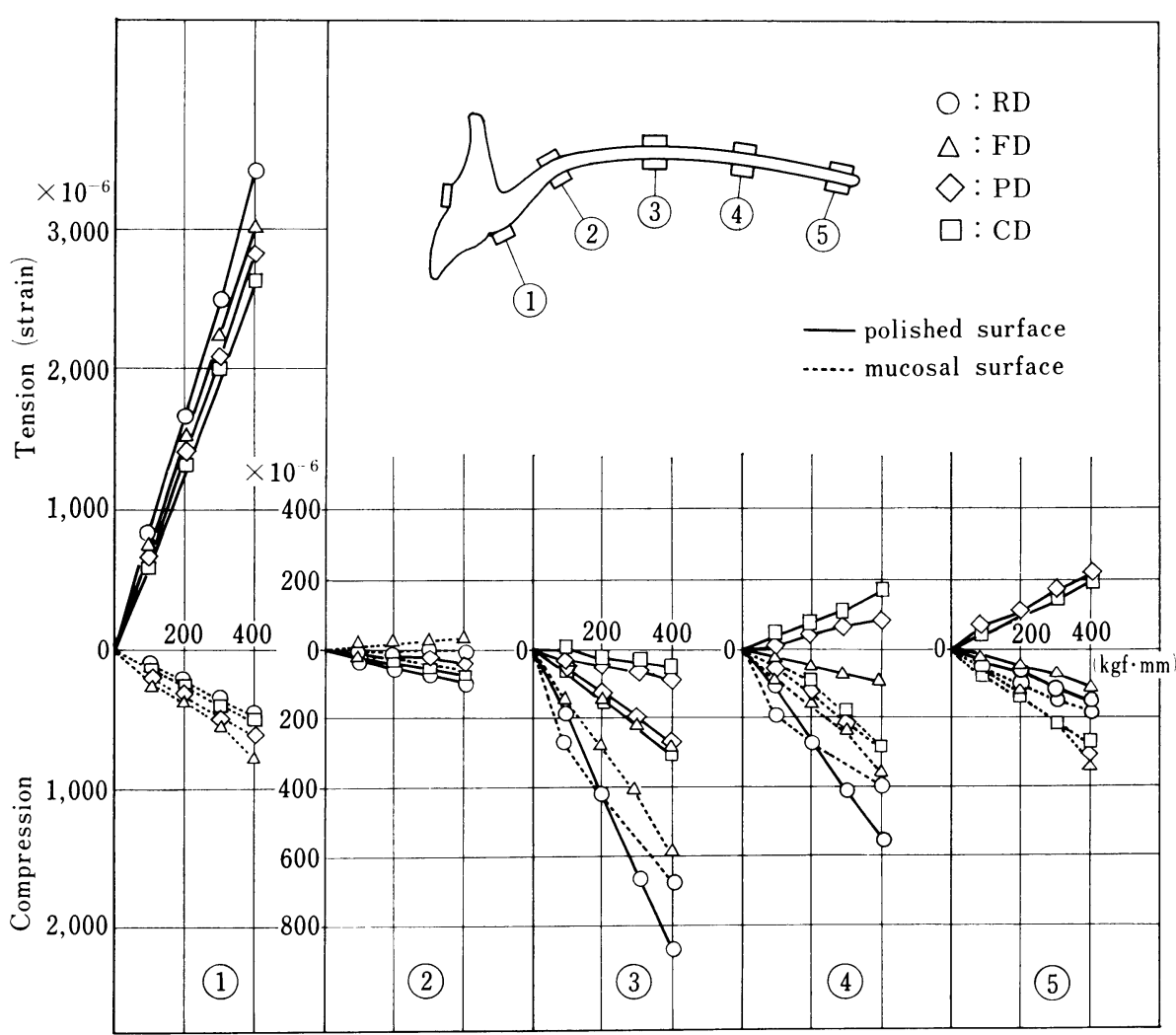

戍 5 上顎全部床義歯口蓋部正中線上の曲げモーメント $(M)$-ひずみ $(\varepsilon)$ 線図 $(M=0$ to $400 \mathrm{kgf} \cdot \mathrm{mm}$ )

的に減少する。特に, 義歯正中線上で顕著な引張 ひずみを生じる切歯乳頭部付近は臨床的にも義歯 床破損の好発部位といわれているが，この部位に おいても，剛性の高い床用材料を用いた義歯床で はひずみが 減少して応力集中が低減し，義歯床 の強度を改善するらえで有効であると考光られ る11)。

\section{3. 義歯床の曲げ強さ}

図 6 は $\mathrm{RD}, \mathrm{FD}, \mathrm{PD}$ 抢よび $\mathrm{CD}$ についての曲 ゲモーメントーたわ多線図を, 表 3 はその結果を 示したものである。各義歯床とも両者の関係は曲 げモーメント $\mathrm{M}=500 \mathrm{kgf} ・ \mathrm{~mm}$ まではほぼ直線 的に経過し，その後わずかながら傾きの減少がみ られ，破壤点に至った。破壞時の曲げモーメント は $\mathrm{CD}$ が最大 $(\mathrm{M}=1,060 \mathrm{kgf} ・ \mathrm{~mm})$ で, $\mathrm{PD}(\mathrm{M}$ $=980 \mathrm{kgf} \cdot \mathrm{mm}), \quad \mathrm{FD}(\mathrm{M}=930 \mathrm{kgf} \bullet \mathrm{mm}), \quad \mathrm{RD}$

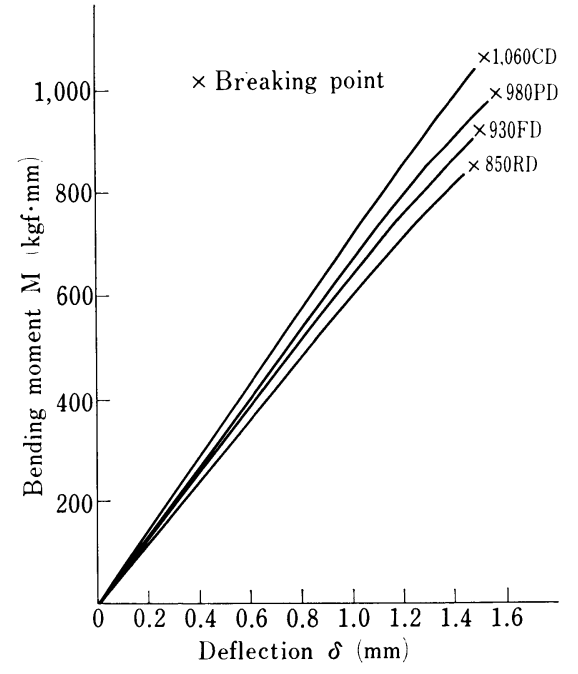

四6 各種試験片の破壊時における曲げモーメ ント $(\mathrm{M})$ ーたわみ $(ð)$ 線図 
求3 破偯峙の曲げモーメントおよびたわ正量

\begin{tabular}{crc}
\hline $\begin{array}{l}\text { Symbol of } \\
\text { denture } \\
\text { base }\end{array}$ & $\begin{array}{c}\text { Bending moment } \\
\text { in fracture } \\
\mathrm{M}(\mathrm{kgf} \cdot \mathrm{mm})\end{array}$ & $\begin{array}{c}\text { Deflection } \\
\delta(\mathrm{mm})\end{array}$ \\
\hline $\mathrm{RD}$ & 850 & 1.48 \\
$\mathrm{FD}$ & 930 & 1.50 \\
$\mathrm{PD}$ & 980 & 1.56 \\
$\mathrm{CD}$ & 1,060 & 1.52 \\
\hline
\end{tabular}

$(\mathrm{M}=850 \mathrm{kgf} ・ \mathrm{~mm})$ の順であり，曲げ強さは RD に比較して FD では約10\%，PD では約15\%，CD では約 $25 \%$ 增加し義幽床の強度们上が認められ た。破塤時の変形量（たわ久量）は各義㐘床とも $1.5 \mathrm{~mm}$ 前後であり, 義歯床間の顕著な差は認め られなからた。破壞は各義幽床とも破折線が上唇

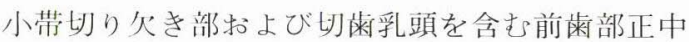
付近のレジン部に生じていた。 RD，FDでは切㐘 乳頭部を含さ正中線方向に床後縁古で破折線が進 久破断していた。PDでは，四７に示すようにス テンレスーレジン境界に沿って破折線が進又破断 していた。また，破断したステンレス衣面には 4-META 含有の接着性レジンは, 肉眼的に残存: していなかった。㘠8はCD の破壤様相を示した ものである。破折線が前歯部レジンおよび床連結 子部にとどまり，網状の床連結子では 4-META を含まない通常の PMMA が残低し, PD の場合 の上うな完全な破断は生じなかった。

口蓋部床用材料として, SUS304 および $\mathrm{Co}-\mathrm{Cr}$ 系合金のように剛性，強度がレジンに比べ著しく 高い材料を顎堤顶を越える口蓋全体に用いたPD, CD では, RD に比べ優れた曲げ強さを示したが, 顕著な強度の问上は認められなかった。また，各 義米休とも曲げ強さは，5測定点の中で最大ひず みを示す切㐘乳頭部を含导前歯部レジンのひずみ 量との関連性が示唆された。また，破壊も同部位 から開始する様相を示すなどから, 咀嚼状態を想 定した一様曲げモー人ントを上顎全部床義蒾に加 光た場合，前歯部レジン，人工歯部扔よび床翼部 では応力が集中し，床口蓋部は義歯床全体の岡 性, 强度の影響が比較的少ない領域であると考党 られる。

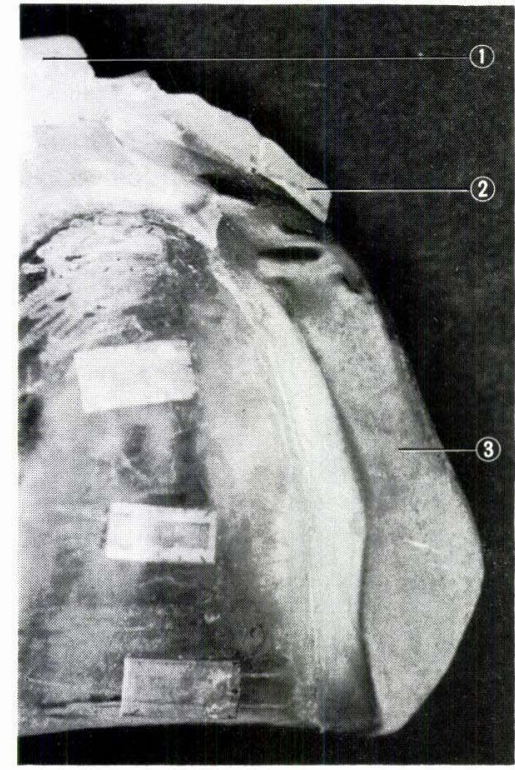

因 7 ステンレス压印床の破壞様相 (1)：人工喽(レジン蔽)，(2)：床用レジン, (3) : 压印床表面

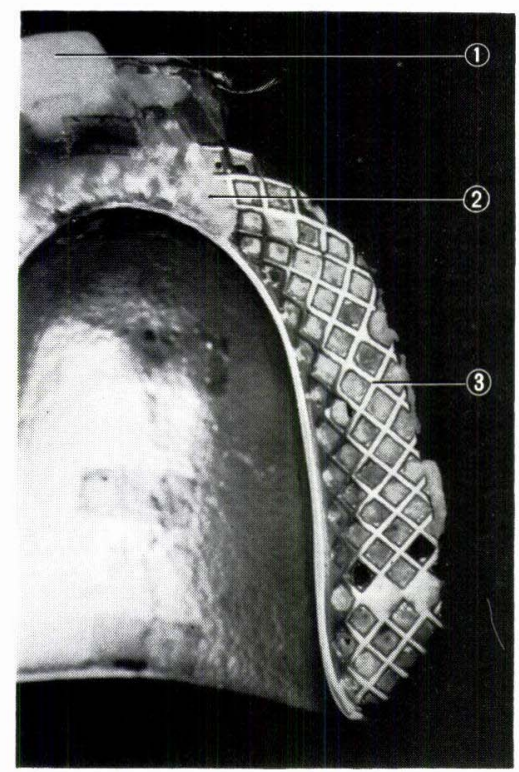

戍8 $\mathrm{Co}-\mathrm{Cr}$ 系鋳造术の破壞様相 1)：人下料(レジン断), (2)：床用レジン, (3：網状の床連結子 
カーボン絾維をレジンに埋入した FD では RD より床口蓋部の厚さを薄くしたにもかかわらず義 歯床の曲げ強さは向上し, 補強効果が示唆され た。したがって，義歯床全体の曲げ強さは床口蓋 部にレジンょり剛性，強度の高い材料を使用する ことにより，顕著な向上は期待できないが切霜乳 頭部を含む前歯部の応力集中の緩和が計られ， $\mathrm{RD}$ より比較的優れた機械的特性を示すものと推 察される。

\section{IV. 総 括}

本報では，上顎全部床義霜を対象に口蓋部床用 材料が義歯床全体の剛性や強度に与える影響につ いて検討を行った。義霜床口蓋部に使用される床 用材料のらち, アクリリックレジン (PMMA), カーボン纎維クロス強化樹脂 (CFRP), 18-8ステ ンレス鋼 (SUS 304) 拉よび Co-Cr 系合金を用い てレジン床抢よび金属床の上顎全部床義㐘試験片 を作製し，機能時の義歯床に加わる応力を想定し た 4 点曲げ試験を垁施した。得られた結果につい て考察を加光, 以下の結論に達した。

1）義柬床口蓋部の厚さ

義歯装着時の違和感との関連性が示唆される義 歯床口蓋部の厚さは, レジン床と比較してステン レス圧印床が最も薄く約 $25 \%, \mathrm{Co}-\mathrm{Cr}$ 系合金鋳造 床約 $38 \%$, カーボン繊維クロス強化樹脂床約 $56 \%$ であり，レジン床より優れた装着感が期待でさ る。

2）義歯床のひずみ分布

義获床正中線上のひずみ分布は, 口蓋部床用材 料が異なるにもかかわらず各義歯床とも切歯乳頭 部付近に拈いて顕著な引張ひずみを示し，床後縁 を含む他の口蓋部では低いひずみ量を示した。㴊 性の高いステンレス圧印床や Co-Cr 系合金鋳造 床では床後縁を含む義歯床口蓋部後方において剛 性の低いレジン休とは異なり，義歯床が粘膜面か ら離れる方向に曲げ挙動を示した。臨床的にも義 歯床破損の好発部位といわれる切歯乳頭部付近で は, 㴊性の高い床用材料を義歯床口蓋部に使用す ることにより顕著な差は認められないもののひず
又量が減少して忘力集中の緩和傾向を示し，義歯 床の強度を改善するら爷で有効であると推察され る。

3）義柬床の曲げ岡性および曲げ強度

咀嚼状態を想定した一様曲げモーメントを上顎 全部床義歯に加えた場合, 前雬部レジン, 人工歯 部扝よび床翼部が義歯床に加わる応力の大部分を 負担し, 床口蓋部は義雨床全体の剛性, 強度には 影響の少ない領域であると考兄られる。しかし， アクリリック樹脂より剛性や強度の高い義歯床用 材料を使用した場合, 臨床上用いられている床の 厚さでは義歯床全体の剛性や強度の著しい改善は 認められないものの, レジン床より比較的優れた 機械的特性を示すことが示唆される。

\section{謝辞}

本論文を終えるにあたり，ご指導とご校閲を賜りま した長尾正憲教授, ならびに東京医科歯科大学医用器 材研究所・宮入裕夫教授に心から感謝致します。また, 本実験にご助言とご援助を戴いた東京医科歯科大学医 用器材研究所・福田秀昭助手に深謝致します。

な抢，本研究は昭和62年度科学研究費補助金 (No. 61570924）により行ったものである。

\section{文献}

1）宮入裕夫, 永井正洋, 村松篤良: 義歯床のFRP 強化と曲げ強度特性. 材料 $26: 1153-1159$, 1977.

2）木村 博, 寺岡文雄, 斉藤隆裕：レジン床の溶 接に関する研究（その 5 ), ポリサルホンのソ ルベント溶接について。歯材器 $1: 351-359$, 1982.

3）永井正洋，宮入裕夫，高山義明：CF クロス強 化材による上顎全部床義菌の薄床化への応用. 強化プラスチックス 29:60-65, 1983.

4）茂木知治：メタクリルレジンと床用 $\mathrm{Co}-\mathrm{Cr}$ 合金 の接着に関する基礎的研究，4-メタクリロキシ エチルトリメリット酸無水物の効果. 補経誌 $23: 660-676,1979$.

5）安田 登, 斉藤良一, 小笠原浩一, 岡部良博, 飯田倫照, 谷田部 優, 藍 稔: 補綴応用を目 的とした 4-META 含有常温重合レジンの研究, 第 2 報 試作品 MB-3 (補修用) と MB-4（リラ イニング用) の理工学的性質と接着強度. 補経 誌 $30: 307-314,1986$.

6）中平良基, 前田芳信, 岡组政俊, 大谷隆之, 野 
首孝闰，奥野善彦 : 常温重合型接着性レジンの 有床義歯への応用, 補強線埋入による流し込及 レジン床の補強効果. 補綴誌 $30: 235-241$, 1986.

7）高山義明：上顎レジン全部床義歯の薄床化に関 する研究，(第 2 報）口蓋形態の差異がレジン薄 床義歯に及ぼす影響について。歯理工誌 21 : 48-63, 1980.

8）早川 厳, 今井基泰, 高山義明, 辻善之, 等 澤正幸, 安藤秀二, 米田 豊: 接着性レジンを 用いた圧印床義歯製作法に関する研究. 補経誌 $28: 19-25,1984$.
9）茂木正邦：4-META/MMA-TBB レジンの蒾科 矯正学的研究 (II), メタルに対する接着性につ いて. 日矯歯誌 $41: 272-282,1982$.

10）平林 茂, 中西 敏, 立野治雄, 三宅裕昭, 平 澤 忠: 歯科用メタクリルレジンに関する研 究，(第10報）加熱重合レジン, ヒートショッ クレジン，流し込みレジンおよび常温重合レジ ンの物理的性質について. 歯材器 $3: 350-358$, 1984.

11）高山義明：接着性レジンを応用した圧印床義歯 の機械的特性に関する研究. 補綴誌 31 ：985990, 1987. 